\title{
First fossil representative of the net-winged beetles genus Plateros Bourgeois, 1879 (Insecta: Coleoptera: Lycidae) from Mexican amber, with redescription of Electropteron avus gen.n., sp.n. from Dominican amber and a note on the time of origin of the family
}

\author{
Первый ископаемый представитель жкуков-краснокрылов рода Plateros \\ Bourgeois, 1879 (Insecta: Coleoptera: Lycidae) из мексиканского \\ янтаря, с переописанием Electropteron avus gen.n., sp.n. из домини- \\ канского янтаря и заметкой о времени возникновения семейства
}

\author{
Sergey V. Kazantsev \\ C.В. Казанцев
}

Insect Centre, Donetskaya 13-326, Moscow 109651, Russia. E-mail: kazantss@mail.ru Инсект-центр, ул. Донецкая 13-326, Москва 109651, Россия.

KEY WORDS: Coleoptera, Lycidae, new species, taxonomy, Mexican, Dominican, Baltic and Burmese amber, palaeoentomology, Cretaceous, Eocene, Early Miocene.

КЛЮЧЕВЫЕ СЛОВА: Coleoptera, Lycidae, новый вид, таксономия, мексиканский, доминиканский, балтийский и бирманский янтарь, палеоэнтомология, мел, эоцен, ранний миоцен.

ABSTRACT. A new species of net-winged beetles, Plateros jardinesi sp.n., is described from the Early Miocene (23-15 myo) Mexican amber from Chiapas, Mexico, being the first indication of the tribe Platerotini in amber. The taxon Electropteron avus gen.n., sp.n. from Dominican amber is redescribed, as it was published in 2012 in an online-only journal and was thus unavailable under provisions of the ICZN. The taxonomic position of Burmese amber tribe Cretolycini Tihelka et al., 2019 and the time of origin of the family is discussed. A list of the currently known amber netwinged beetles is provided.

РЕЗЮМЕ. Из мексиканского янтаря из штата Чьяпас, Мексика, относимого к раннему миоцену, описывается новый вид жуков-краснокрылов, Plateros jardinesi sp.n., что является первым указанием трибы Platerotini из янтаря. Из доминиканского янтаря переописывается таксон Electropteron avus gen.n., sp.n., поскольку его изначальное описание в 2012 году было опубликовано только в он-лайн версии журнала и, таким образом, было непригодным в соответствии с положениями Международного кодекса зоологической номенклатуры. Обсуждается таксономическое положение трибы Cretolycini Tihelka et al., 2019 из бирманского янтаря и время возникно- вения семейства. Приводится список всех известных из янтаря Lycidae.

\section{Introduction}

Amber net-winged beetles had for a long time been known only from Eocene Baltic amber, with a 'Lygistopterus sp.' and some other extant genera signalled as early as in 1910 [Klebs, 1910] and the first amber lycid taxon, Pseudaplatopterus Kleine, 1940, discovered in the middle of the XXth century [Kleine, 1940; 1941]. Another three Baltic amber taxa were added after about half a century by Winkler [1987], but only one of the three genera described by him, Kolibaceum Winkler, 1987, retained its status. Recently, the Baltic amber lycid taxa were complemented with Protolopheros Kazantsev, 2013 [Kazantsev, 2013] and Protolycus Kazantsev, 2019 [Kazantsev, 2019].

As of late, net-winged beetles turned out to be present not exclusively in Baltic amber, but in some of the other ambers as well - Miocene Dominican amber yielded Electropteron Kazantsev, 2012 [Kazantsev, 2012c], and a representative of the extant Caribbean genus Cessator Kazantsev, 2009 [Ferreira, Ivie, 2017], while Burmolycus Bocak et al., 2019, Cretolycus Tihelka et al., 2019

How to cite this article: Kazantsev S.V. 2020. First fossil representative of the net-winged beetles genus Plateros Bourgeois, 1879 (Insecta: Coleoptera: Lycidae) from Mexican amber, with redescription of Electropteron avus gen.n., sp.n. from Dominican amber and a note on the time of origin of the family // Russian Entomol. J. Vol.29. No.4. P.377-387. doi: 10.15298/rusentj.29.4.04 
and Prototrichalus Molino-Olmedo et al., 2020 were discovered in Cretaceous Burmese amber [Bocak et al., 2019; Tihelka et al., 2019; Molino-Olmedo et al., 2020].

The amber lycids discovered to date, although not numerous at the alfa taxonomic level (just eleven species) turned out to belong to quite a variety of tribes: Lycini, Erotini, Dictyopterini, Lopherotini (in Baltic amber), Leptolycini (in Dominican amber), Cretolycini, Burmolycini and Metriorrhynchini (in Burmese amber).

Although net-winged beetles have been known from Miocene Dominican amber since 2012, they have not been registered in the related Mexican amber. However, the possibility to study amber inclusions from the Museum of Lúzmica in San Cristobal (Chiapas, Mexico) lead to discovery of a lycid. The inclusion could be undoubtedly referred to the extant genus Plateros Bourgeois, 1878 , one of the largest in the family and one of the most widespread, including over 900 species distributed in all biogeographic realms, mostly in the Palaeotropics [e.g. Kleine, 1933; Kazantsev, 2011], with over 50 species in Mexico [Zaragoza Caballero, 1999]. The inclusion agrees in every detail with the diagnosis of the genus, but apparently represents a new species due to the combination of characters used in defining living congeners. It is the first Mexican amber taxon of this family and the first fossil taxon of tribe Platerotini (Lycinae).

In the meanwhile the taxon Electropteron avus Kazantsev, 2012 from Miocene Dominican amber turned out to be published in an online-only journal without registration in ZooBank [Kazantsev, 2012c]. As it is thus unavailable under provisions of the ICZN, it needs to be formally redescribed. The description of these taxa, as well as notes on placement of the Cretaceous Burmese amber tribe Cretolycini Tihelka et al., 2019 and the origin of the family are presented below.

\section{Material and Methods}

Mexican and Dominican ambers are referred to the Early Miocene, ca. 23-15 mya [e.g., Riquelme et al., 2014]. The amber pieces had been cut and polished, and then examined with a Zeiss zoom stereoscopic dissect-

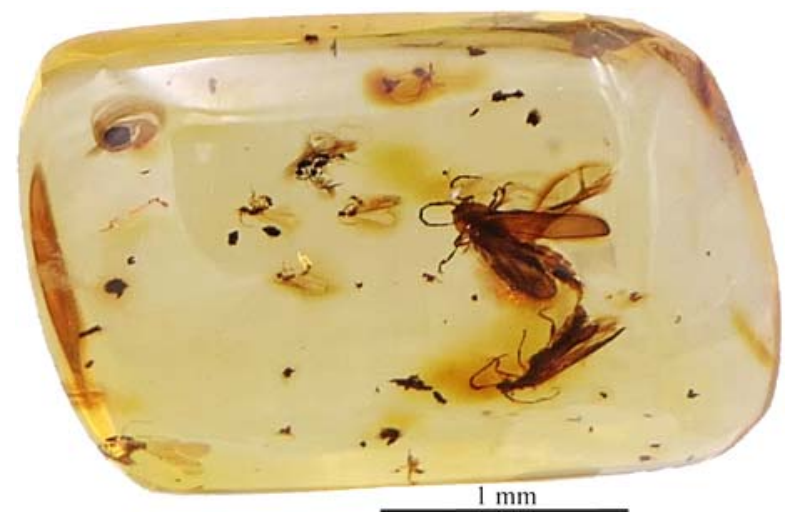

Fig. 1. General view of the amber piece with Plateros jardinesi sp.n. Рис. 1. Общий вид образца янтаря с Plateros jardinesi sp.n. ing microscope, as well as an MSP-1 zoom stereoscopic dissecting microscope with $\mathrm{x} 8-\mathrm{x} 80$ magnification range. Photographs were taken with Canon EOS 450D camera and Nikon M Plan 10x-40x and Luminar 18-40 mm lens (for Plateros jardinezi sp.n.) and Canon EOS 6D camera and Canon MP-E $65 \mathrm{~mm}$ lens (for Electropteron avus gen.n., sp.n.).

The following acronyms are used in the paper: ICM - Insect Centre, Moscow; MLSC - Museum of Lúzmica, San Cristobal, (Chiapas, Mexico).

\section{Taxonomy}

Lycidae Laporte, 1840

Lycinae Laporte, 1840

Platerotini Kleine, 1928

Plateros Bourgeois, 1879

Type species: Eros brasiliensis Lucas, 1857 (subsequent designation by Zaragoza, 1999).

\section{Plateros jardinesi Kazantsev, sp.n.}

Figs 1-6.

MATERIAL: Holotype, $0^{7}$, specimen No. MLSC 0001, Mexican amber, Early Miocene, Simojovel area, Chiapas, Mexico) (MLSC); Paratype, + , same data, in copula with the Holotype (MLSC).

SYNINCLUSIONS. Several Hymenoptera and Diptera.

DESCRIPTION. Male. Dark brown to black (Figs 2-4).

Head transverse, narrowed posteriorly. Eyes moderately large, eye diameter ca. 1.5 times smaller than head width behind eyes. Mandibles slender, relatively long, evenly rounded. Palps slender, ultimate palpomeres securiform, distally noticeably narrowed. Antennae 11-segmented, slightly dentate, extending to elytral two fifths, with antennomere $3 \mathrm{ca}$. 1.6 times longer than pedicel (antennomere 2) and ca 1.5 times shorter than antennomere 4 ; antennal pubescence relatively short and suberect (Figs 2-4).

Pronotum transverse, semicircular, with explanate sides, rounded anterior and short rectangular posterior angles (Figs 2-4).

Elytra elongate, ca. 4 times longer than wide, somewhat narrowing distally, with almost equally developed and almost converging near apex primary costae, interstices with double rows of small subquadrate cells; uniform suberect pubescence (Figs 2-4).

Legs relatively short, with robust femora and narrow tibiae, tibiae and femora straight, subequal in length; hind tarsomere ratio: $2: 1.6: 1.1: 1: 2.4$; tibiae with distinct spurs; tarsomeres $2-4$ conspicuously widened, tarsomeres $2-4$ split almost to base; claws simple (Figs 2-4). Ultimate tergite triangularly incised distally; ultimate ventrite oval, narrowing distally (Figs 2-5).

Aedeagus with noticeably bent and dented about the middle median lobe, with robust proximal and narrower distal halves (apex of median lobe and phallobase obscured by overlaying segments) (Figs 5-6).

Length (from anterior head margin to end of elytra): 5.3 (male)-6.2 (female) mm; width (at humeri): 1.4 (male)-1.5 (female) $\mathrm{mm}$.

Female. Similar to male, but somewhat larger, with smaller eyes and somewhat shorter and less dentate antennae. External genitalia elongate coxites and elongate tapering distally styli with a bunch of long hairs at apex (Fig. 5). 
ETYMOLOGY. The new species is named after Mr. Antonio Ramirez Jardines (San Cristobal, Chiapas, Mexico) through whose courtesy I was able to study the Mexican amber inclusions under his care.
DIAGNOSIS. Plateros jardinezi sp.n. seems to resemble $P$. cadenai Zaragoza Caballero, 1999 in the shape of the aedeagus [Zaragoza Caballero, 1999], but is easily separable by the distinctly more robust proximal and

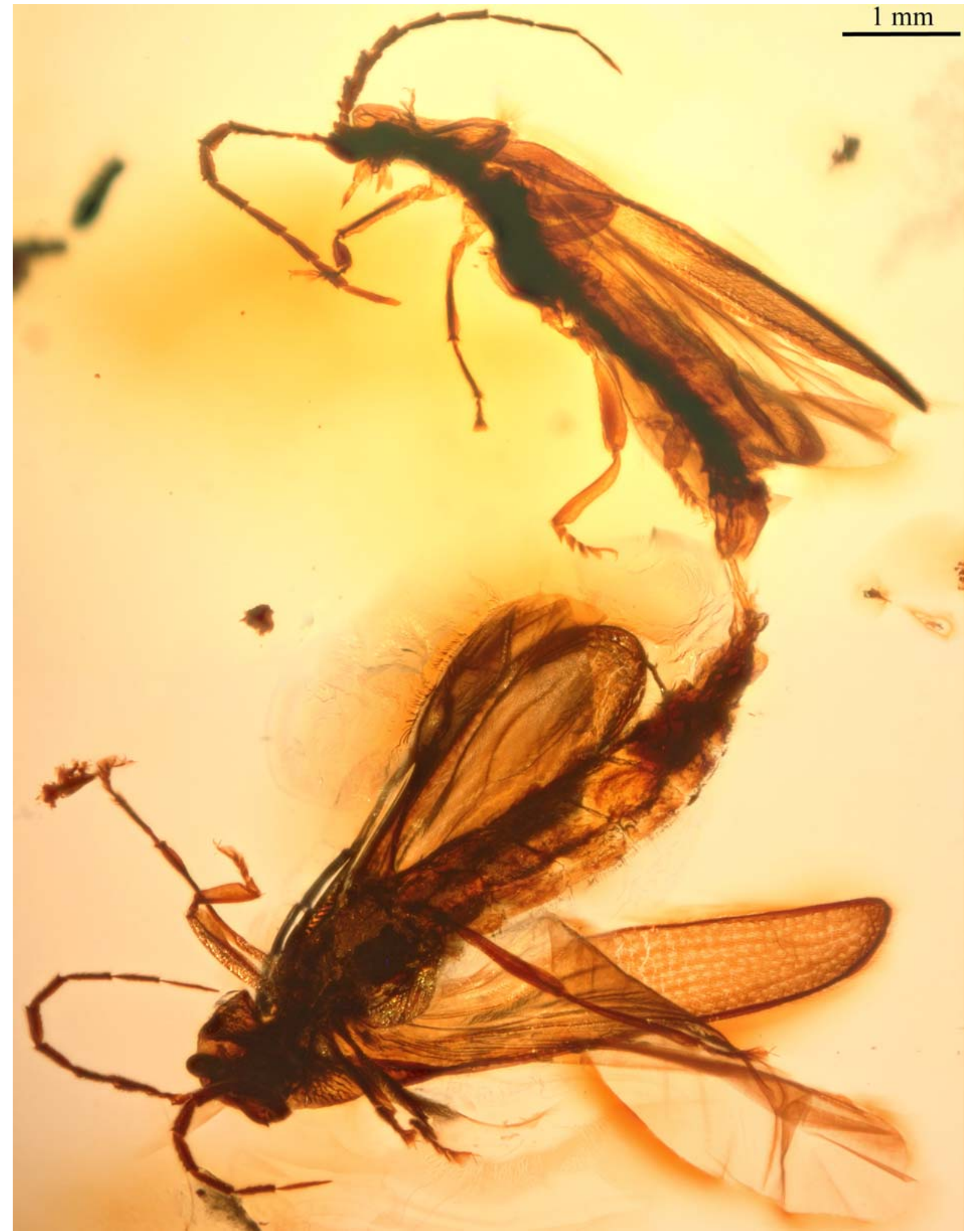

Fig. 2. General view of Plateros jardinesi sp.n., holotype male (above) and paratype female (below) in copula.

Рис. 2. Общий вид Plateros jardinesi sp.n., голотип, самец (сверху) и паратип, самка (снизу), во время копуляции. 


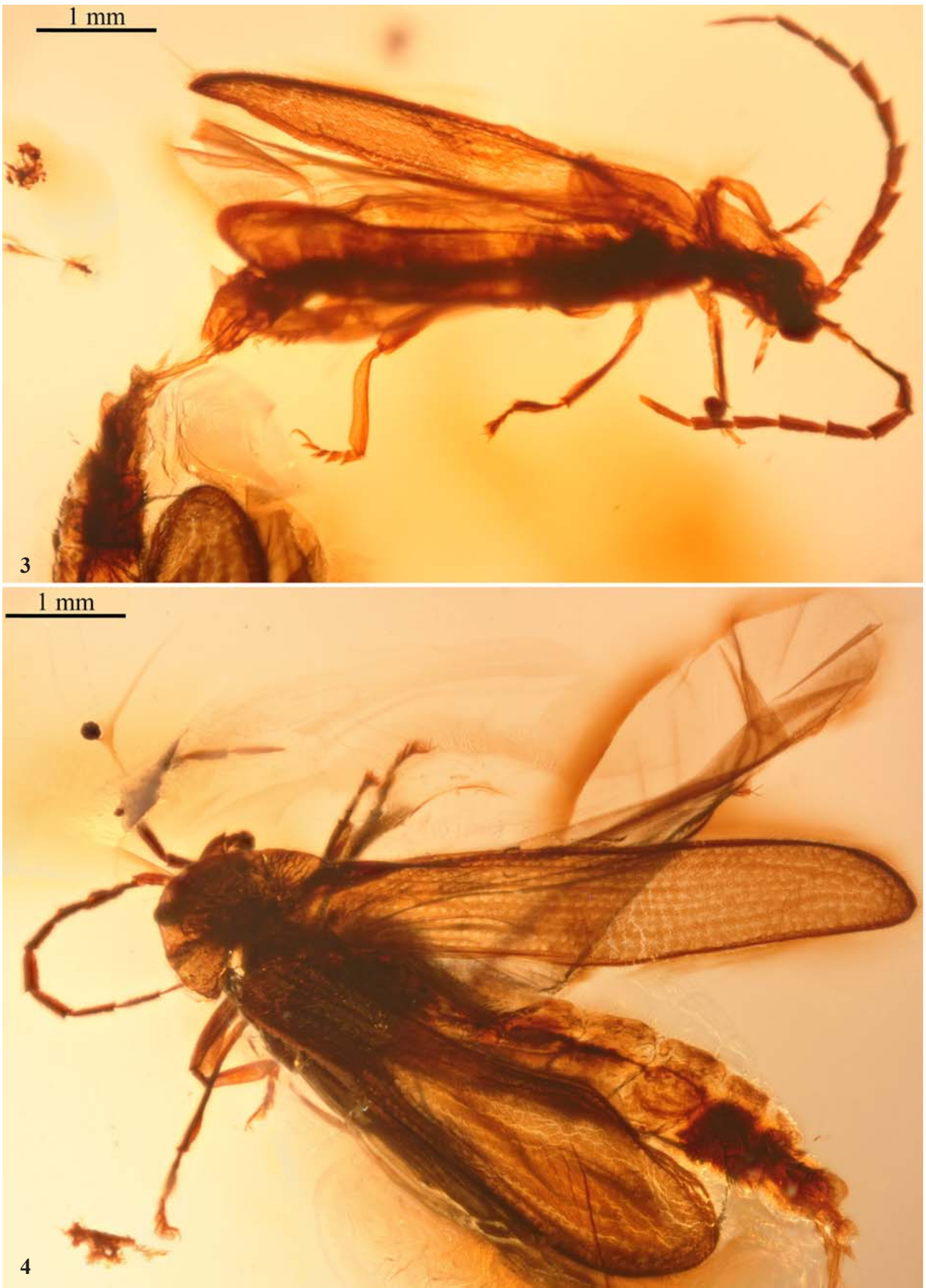

Figs 3-4. General view of Plateros jardinesi sp.n., 3 - holotype male, dorso-laterally; 4 - paratype female, dorsally. Рис. 3-4. Общий вид Plateros jardinesi sp.n., голотип, самец (сверху) и паратип, самка (снизу), во время копуляции. 
straighter distal halves of the median lobe of the aedeagus (Figs 5-6).

REMARKS. The inclusion is well preserved in a relatively large, $30 \times 19 \times 11 \mathrm{~mm}$, almost rectangular and clear amber piece.

\section{Leptolycinae Leng et Mutchler, 1921} Leptolycini Leng et Mutchler, 1921

\section{Electropteron Kazantsev, gen.n.}

Type species: Electropteron avus Kazantsev, sp.n.

DESCRIPTION. Adult male. Alate, slender, elongate (Figs 7-8). Head subquadrate, slightly narrowed behind eyes. Fastigium right-angled. Eyes relatively small, spherical. Maxillary palps slender, with ultimate palpomere pointed distally. Gula prominent. Antennal prominence conspicuous, anten- nal sockets approximate. Antenna 11-segmented, moderately long, slightly widening distally; antennomeres 4-11 flattened, antennomeres 2 and 3 short, transverse, subequal in length; pubescence on antennomeres 4-11 relatively short and erect (Figs 7-9).

Pronotum small, ca. 6 times shorter than elytra, transverse, trapezoidal, with obscure median impression in posterior third; posterior angles produced laterally (Fig. 7). Prosternum short, V-shaped (Figs 8, 10). Thoracic spiracles small, not projecting beyond coxae. Mesoventrite transverse, short. Mesonotum with rather prominent, elongate scutellum (Fig. 7).

Elytra long, narrowing and dehiscent distally, covering abdomen, except genital capsule, with two noticeable primary costae (presumably, costae 2 and 4); interstices irregularly areolate; short and erect elytral pubescence uniform (Fig. 7).
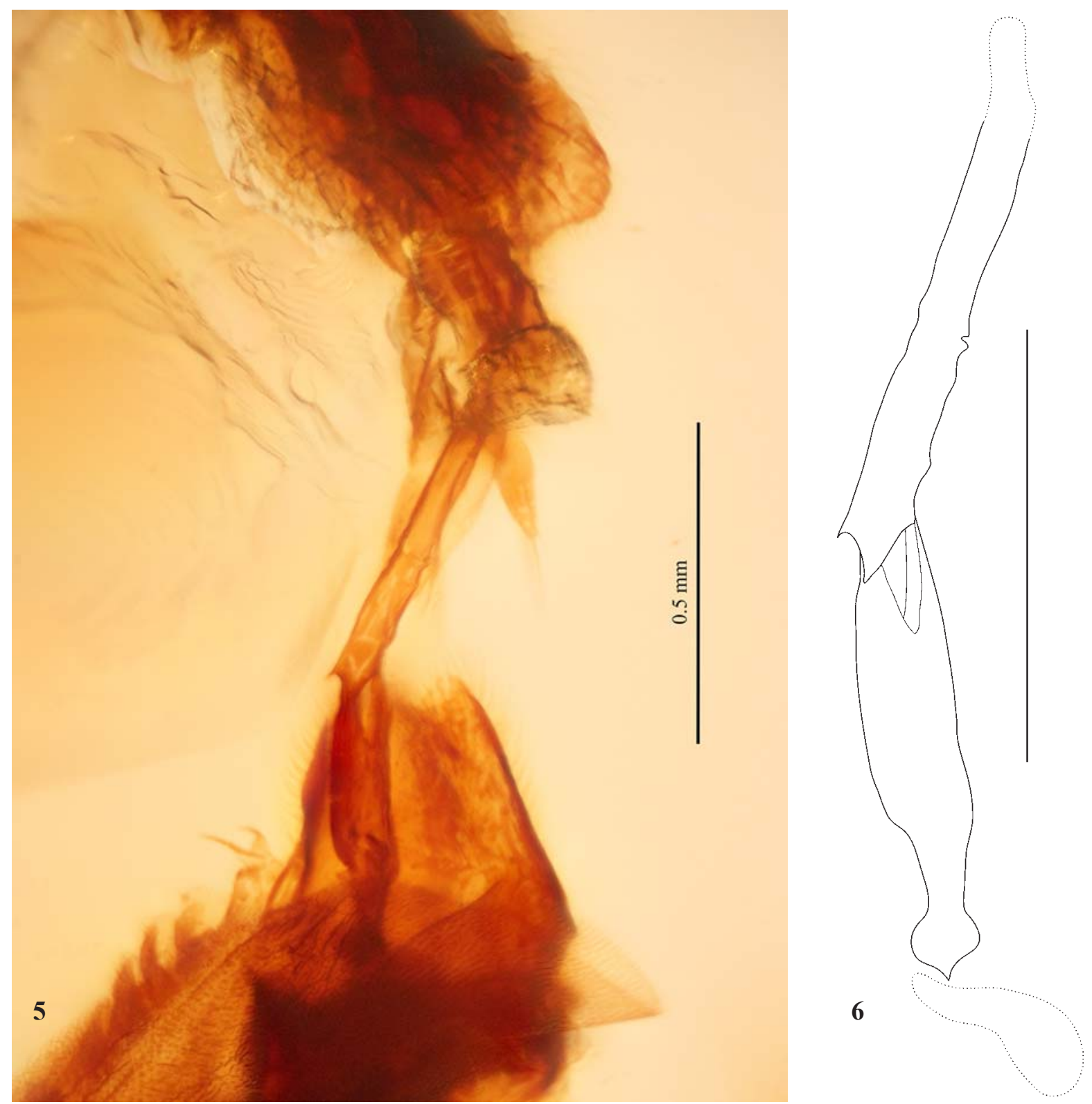

Fig. 5. Terminal abdominal segments and genitalia of Plateros jardinesi sp.n., holotype male (below) and paratype female (above). Рис. 5. Вершинные сегменты брюшка и генитали Plateros jardinesi sp.n., голотипа, самца (снизу) и паратипа, самки (сверху).

Fig. 6. Aedeagus of Plateros jardinesi sp.n., holotype male, laterally. Scale bar: $0.5 \mathrm{~mm}$.

Рис. 6. Эдеагус Plateros jardinesi sp.n., голотип, самец, сбоку. Масштабная линейка: 0.5 мм. 
Metaventrite transverse, with acute posterior angles; discrimen complete, attaining to mesosternum.

Pro- and mesocoxae elongate; metacoxae approximate; angle between metacoxae ca. $90^{\circ}$. Legs slender; trochanters elongate, but considerably shorter than femurs, cylindrical, connected to femora distally; femurs and tibiae flattened, tibiae straight, widened distally; tarsomeres 1-4 narrow, without plantar pads; all claws simple. Ultimate sternite and tergite elongate, pointed at apex (Figs 7-8, 11).

Female. Unknown.

ETYMOLOGY. The name of the genus is derived from 'electron' and 'pteron', the Greek for 'amber' and 'wing'. Gender neuter.

DIAGNOSIS. Electropteron gen.n. appears to be related to the extant genus Tainopteron Kazantsev, 2009, from Puerto Rico [Kazantsev, 2009], distinguishable by the flattened and distally slightly widening antennomeres 4-11, less transverse pronotum and more elongate elytra completely covering the folded wings (Fig. 7). The new genus is different from Leptolycus Leng et Mutchler, 1922, another Greater Antillean extant endemic [Kazantsev, 2009], by the flattened antennomeres 4-11 with even edges and short pubescence, transverse pronotum with explanate sides and short V-shaped prosternum (Figs 7-8, 10). On the other hand, Electropteron gen.n. is somewhat similar to Ceratoprion Gorham, 1884, distributed in the highlands of Central America and the Ands south to Ecuador, differing by the non-serrate antennomeres 4-11 and their erect pubescence and by the absence of the median longitudinal pronotal carina.

REMARKS. Electropteron avus gen.n., sp.n., which is evidently close to some of the extant Leptolycini from Hispaniola and Puerto Rico, is tentatively attributed to the same tribe, although the tribe itself with the unusually wide range of morphologies of its members [e.g., Kazantsev, 2009; 2017] may prove to represent several independent lineages. The tribe Leptolycini is confined to Central America, Greater Antilles, and mostly northern part of South America. The discovery of a representative of this group in the ca. 20 myo Dominican amber, actually in the area of the current distribution of its close relatives, gives further clues for the reconstruction of the history and phylogenetics of the family.

\section{Electropteron avus Kazantsev, sp.n.}

Figs 7-11.

MATERIAL: Holotype, Oㄱ, specimen No. 09155/2198988208, Dominican Amber, Miocene (ICM).

SYNINCLUSIONS. Two Cecidomyiidae (Diptera).

DESCRIPTION. Male. Dark brown to black; antennomere 11, pronotum, scutellum, elytra proximally, at scutellar

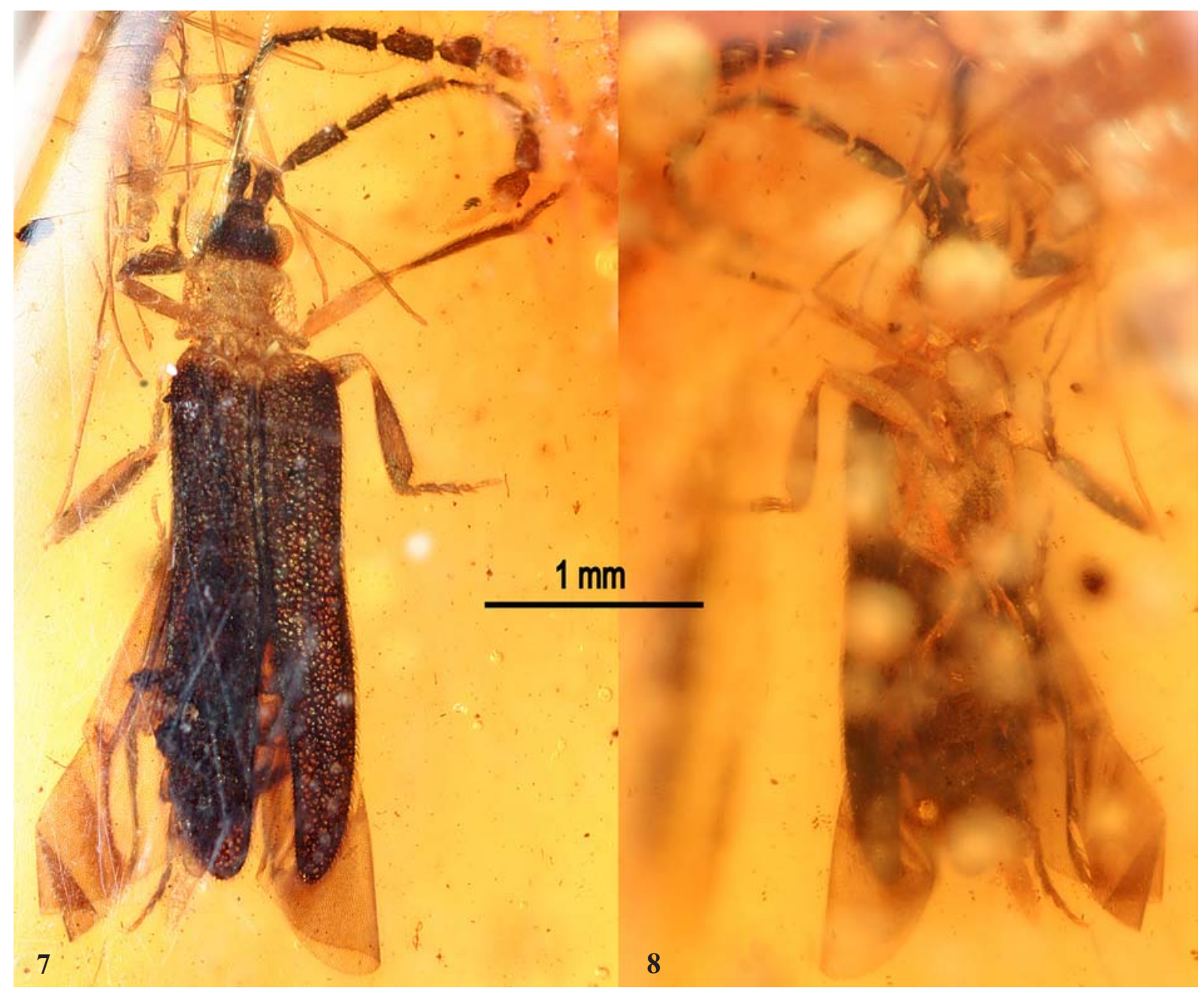

Figs 7-8. General view of Electropteron avus gen.n., sp.n., holotype male: 7 - dorsally; 8 - ventrally.

Рис. 7-8. Общий вид Electropteron avus gen.n., sp.n., голотип, самец: 7 - сверху; 8 - снизу. 


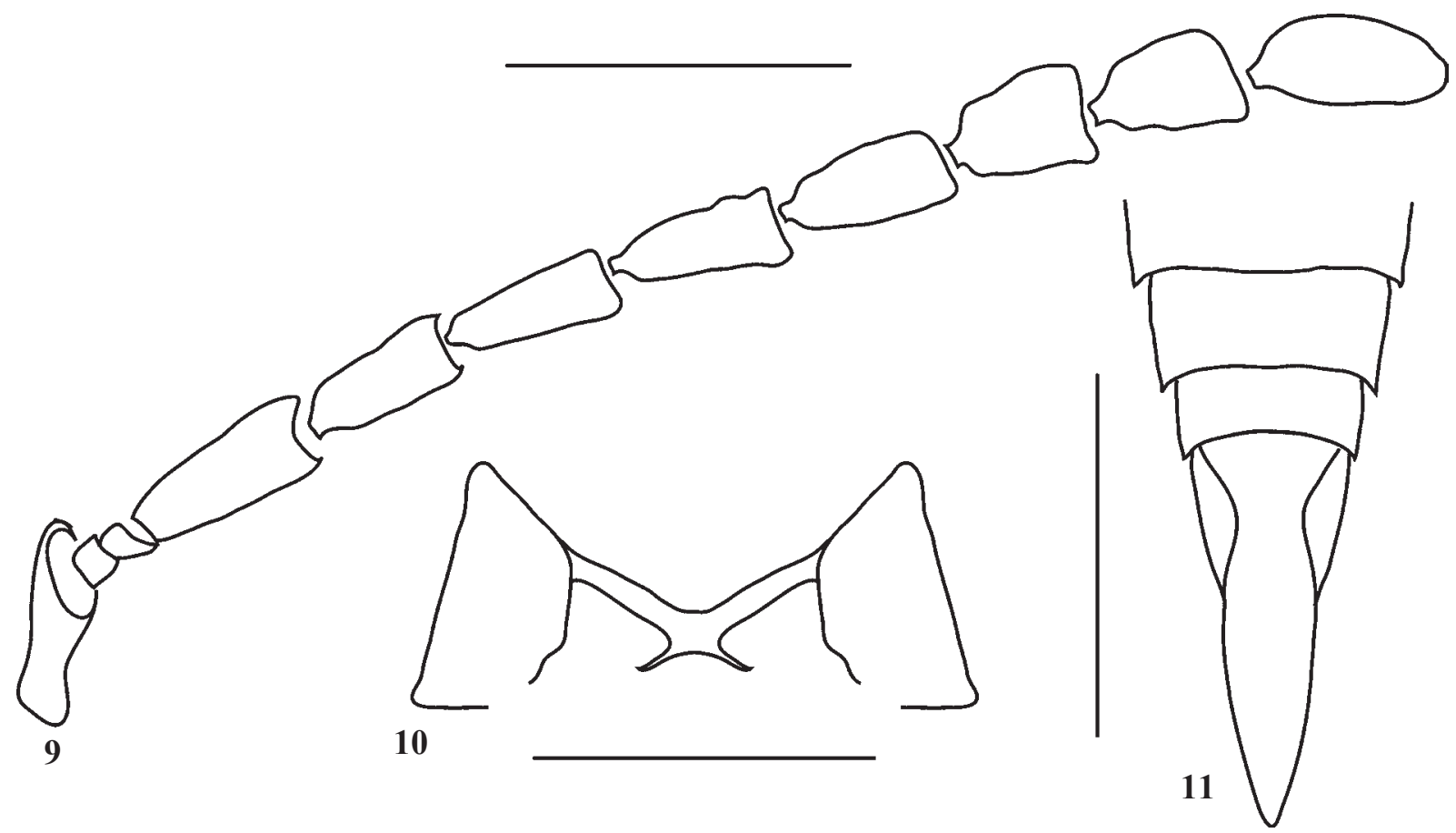

Figs 9-11. Details of Electropteron avus gen.n., sp.n., holotype male: 9 - antenna; 10 - prosternum; 11 - terminal abdominal segments ventrally. Scale: $0.5 \mathrm{~mm}$.

Рис. 9-11. Детали строения Electropteron avus gen.n., sp.n., голотип, самец: 9 - антенна; 10 - переднегрудь; 11 - вершинные сегменты брюшка, снизу. Масштабная линейка: 0.5 мм.

level, meso- and metaventrites, genital capsule, coxae, trochanters and femurs yellowish.

Head with deep impression behind antennal prominence. Eyes small, interocular dorsal distance over 2 times greater than eye radius. Antennae attaining to elytral middle, with antennomere 3 subequal in length to pedicel (antennomere 2) and 5.5 times shorter than antennomere 4 (Figs 7-9).

Pronotum transverse, ca. 1.5 times as wide as long, slightly narrowing anteriorly, with almost straight anterior margin, noticeable anterior and small acute posterior angles. Scutellum parallel-sided and medially emarginate at apex (Fig. 7).

Elytra elongate, 3.3 times as long as wide at humeri, narrowing distally, dehiscent in distal two fifths, with two primary costae reaching their apices and costa 1 noticeable in proximal fourth (Fig. 7).

Legs relatively short, tibiae subequal in length to femurs (Figs 7-8)

Length (from anterior head margin to end of abdomen): $3.3 \mathrm{~mm}$. Width (humerally): $0.7 \mathrm{~mm}$.

Female. Unknown.

ETYMOLOGY. The name of the new species is derived from 'avus', the Latin noun for 'grandfather', alluding to its hypothetic ancestry to some of the extant Greater Antillean lycids.

DIAGNOSIS. Electropteron avus sp.n., the only known representative of the genus, is easily distinguishable from the described extant lycids, as well as from the other amber lycid taxa, by the generic characters.

The list of the currently known amber net-winged beetles includes the following taxa:

\author{
Lycidae Laporte, 1840 \\ Lycinae Laporte, 1840 \\ Lycini Laporte, 1840
}

$\uparrow$ Protolycus Kazantsev, 2019

Protolycus Kazantsev, 2019: 329. Type species Protolycus gedaniensis Kazantsev, 2019 (original designation)

$\dagger$ †edaniensis Kazantsev, 2019: 330. Eocene Baltic amber. Several extant genera of Lycini worldwide (Fig. 13)

Platerotini Kleine, 1929

Plateros Bourgeois, 1879

Plateros Bourgeois, 1879: xix. Type species Eros brasiliensis Lucas, 1857 (subsequent designation by Zaragoza, 1999)

$\dagger$ †jardinesi Kazantsev, 2020, sp.n. Miocene Mexican amber. The only fossil species from a genus with over 900 species distributed in all biogeographic realms, mostly in the Palaeotropics [e.g. Kleine, 1933; Kazantsev, 2011].

Metriorrhynchini Kleine, 1926

$\uparrow$ Prototrichalus Molino-Olmedo, Ferreira, Branham et Ivie, 2020

Prototrichalus Molino-Olmedo, Ferreira, Branham et Ivie, 2020: 2. Type species Eros brasiliensis Lucas, 1857 (original designation)

$\uparrow$ meiyingae Molino-Olmedo, Ferreira, Branham et Ivie, 2020: 6. Cretaceous Burmese amber.

$\nmid$ milleri Molino-Olmedo, Ferreira, Branham et Ivie, 2020: 6. Cretaceous Burmese amber.

$\dagger$ sepronai Molino-Olmedo, Ferreira, Branham et Ivie, 2020: 6. Cretaceous Burmese amber. 
Erotinae Leconte, 1881

Erotini Leconte, 1881

$\uparrow$ Pseudaplatopterus (Pseudaplatopterus) Kleine, 1940

Pseudaplatopterus Kleine, 1940: 179. Type species Pseudaplatopterus ascheelei Kleine, 1940 (by monotypy)

†ascheelei Kleine, 1940: 179. Eocene Baltic amber. One fossil species in Baltic amber, with several extant taxa from
Pseudaplatopterus (Eropterus) Green, 1951 in the Eastern Palaearctic and Nearctic (Fig. 14).

Dictyopterini Houlbert, 1922

Helcophorus Fairmaire, 1881

Helcophorus Fairmaire, 1881: cxxix. Type species Helcophorus miniatus Fairmaire, 1881 (original designation)

= Hiekeolycus Winkler, 1987: 66. Type species Hiekeolycus berendti Winkler, 1987 (original designation)

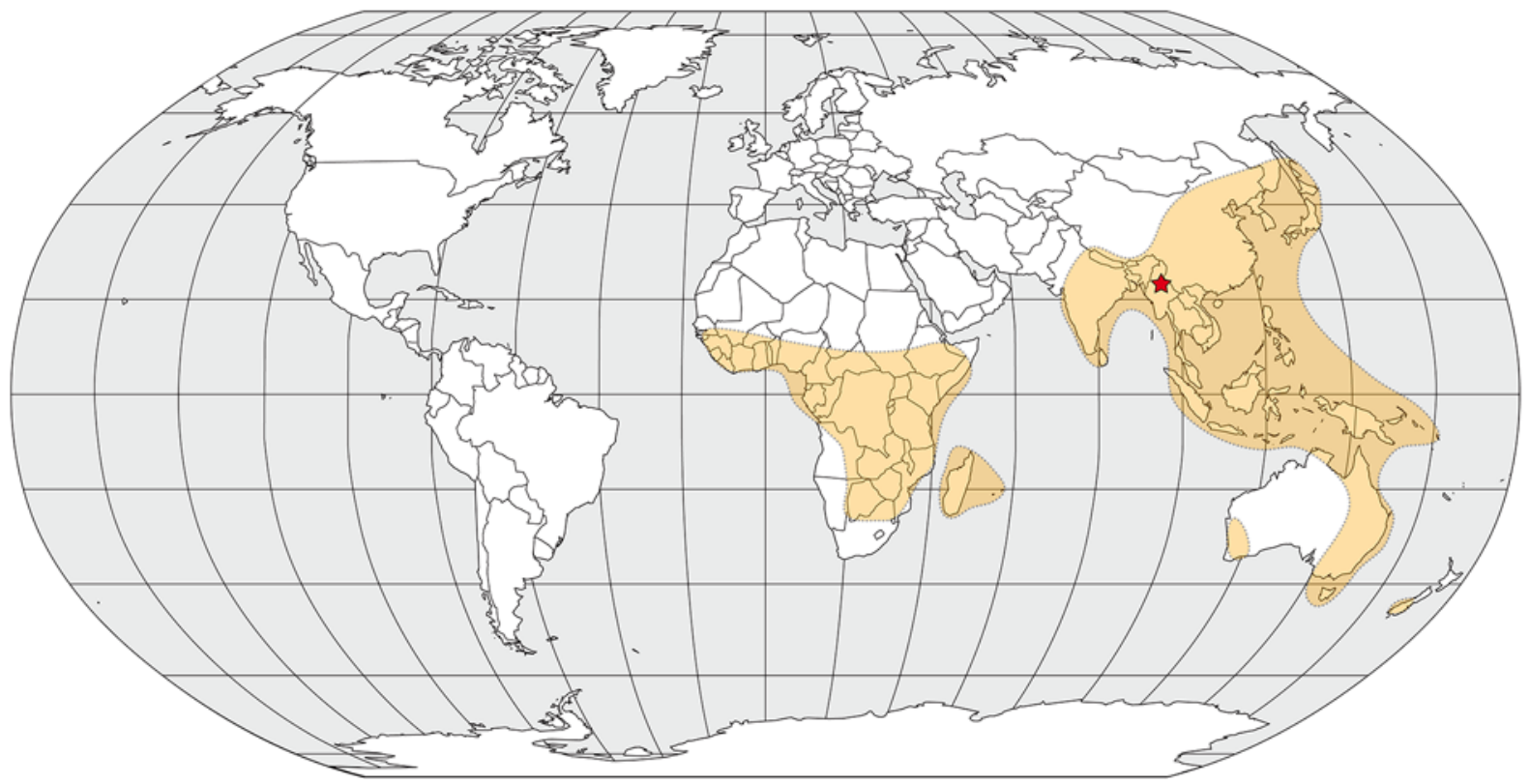

Fig. 12. Current distribution area of the tribe Metriorrhynchini, with locality $(\star)$ for its representative from Burmese amber (Prototrichalus) [after Kazantsev, 2012a, modified].

Рис. 12. Современное распространие трибы Metriorrhynchini, с указанием местоположения ( $\star$ находки её представителя из бирманского янтаря (Prototrichalus) [по Kazantsev, 2012a, с изменениями].

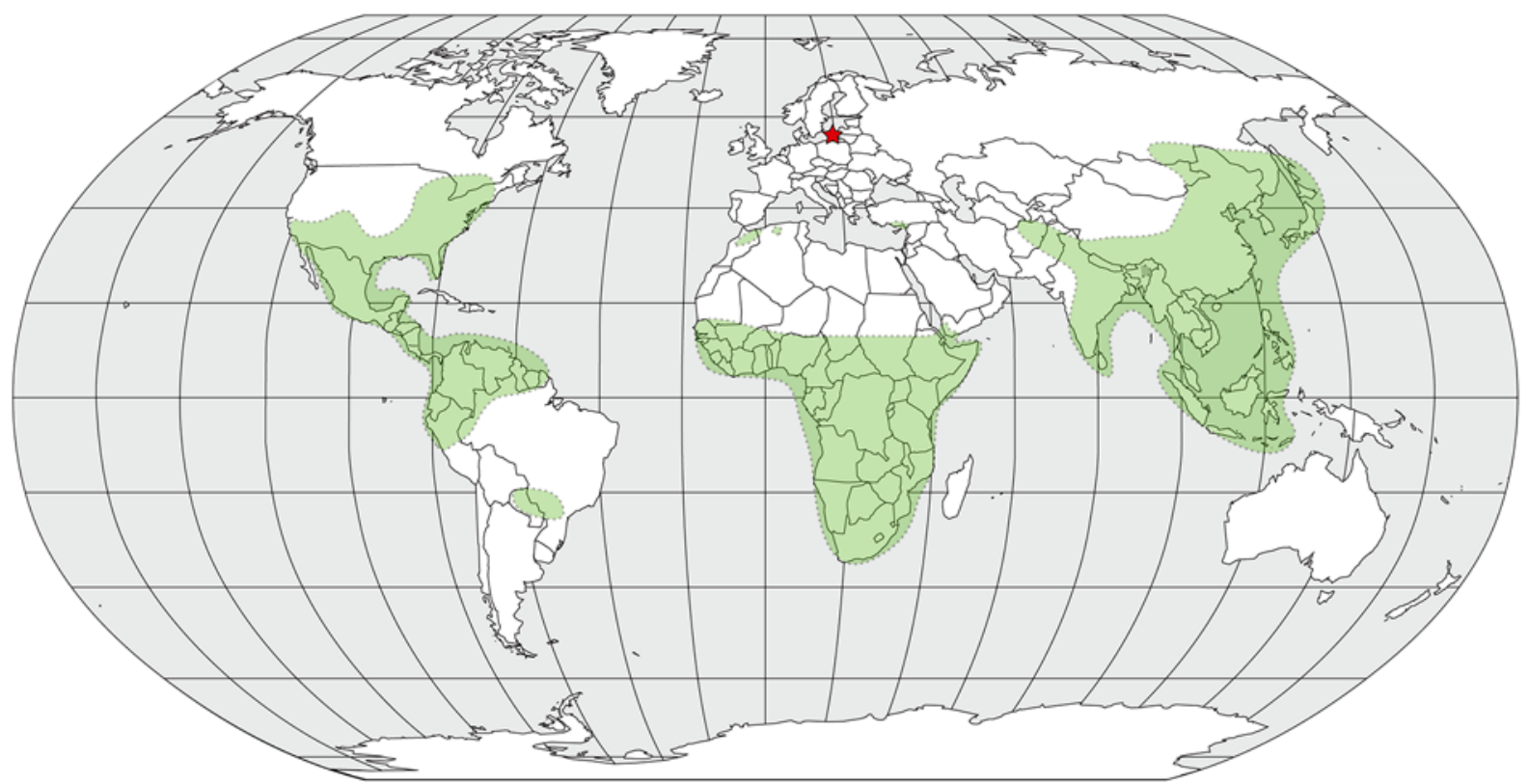

Fig. 13. Current distribution area of the tribe Lycini, with locality $(\star)$ for its representative from Baltic amber (Protolycus).

Рис. 13. Современное распространие трибы Lycini, с указанием местоположения ( $\star$ ) находки её представителя из балтийского янтаря (Protolycus). 
tberendti (Winkler, 1987): 67. Eocene Baltic amber. The only fossil species in Helcophorus, with nine extant taxa in the Eastern Palaearctic (Himalayas, Central China, Northern Vietnam) [Kazantsev, 2015].

$\uparrow$ Kolibacium (Kolibacium) Winkler, 1987

Kolibacium Winkler, 1987: 62. Type species Kolibacium balticum Winkler, 1987 (original designation)
= Pietrzeniukia Winkler, 1987: 68. Type species Pietrzeniukia kunowi Winkler, 1987 (original designation)

†balticum Winkler, 1987: 63. Eocene Baltic amber. One fossil species in Baltic amber, with several extant taxa from Kolibaceum (Laterialis) Kazantsev, 1990 and K. (Tricostaeptera) Kazantsev, 1997 in the Eastern Palaearctic (Japan, Central China, Northern Vietnam and Taiwan). = Pietrzeniukia kunowi Winkler, 1987: 70.

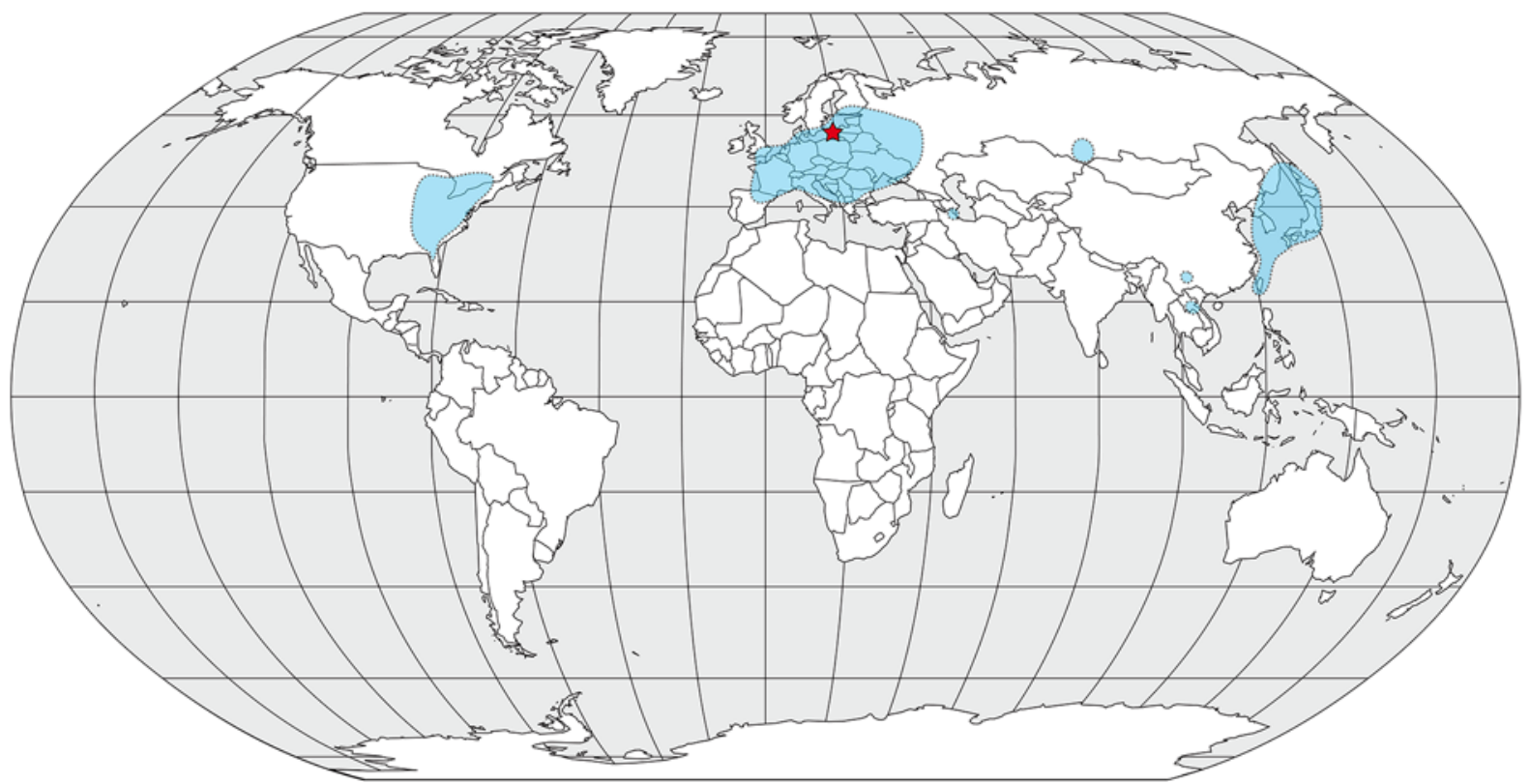

Fig. 14. Current distribution area of the tribe Erotini, with locality $(\star)$ for its representative from Baltic amber (Pseudaplatopterus) [after Kazantsev, 2012b, modified].

Рис. 14. Современное распространие трибы Erotini, с указанием местоположения ( $\star$ ) находки её представителя из балтийского янтаря (Pseudaplatopterus) [по Kazantsev, 2012b, с изменениями].

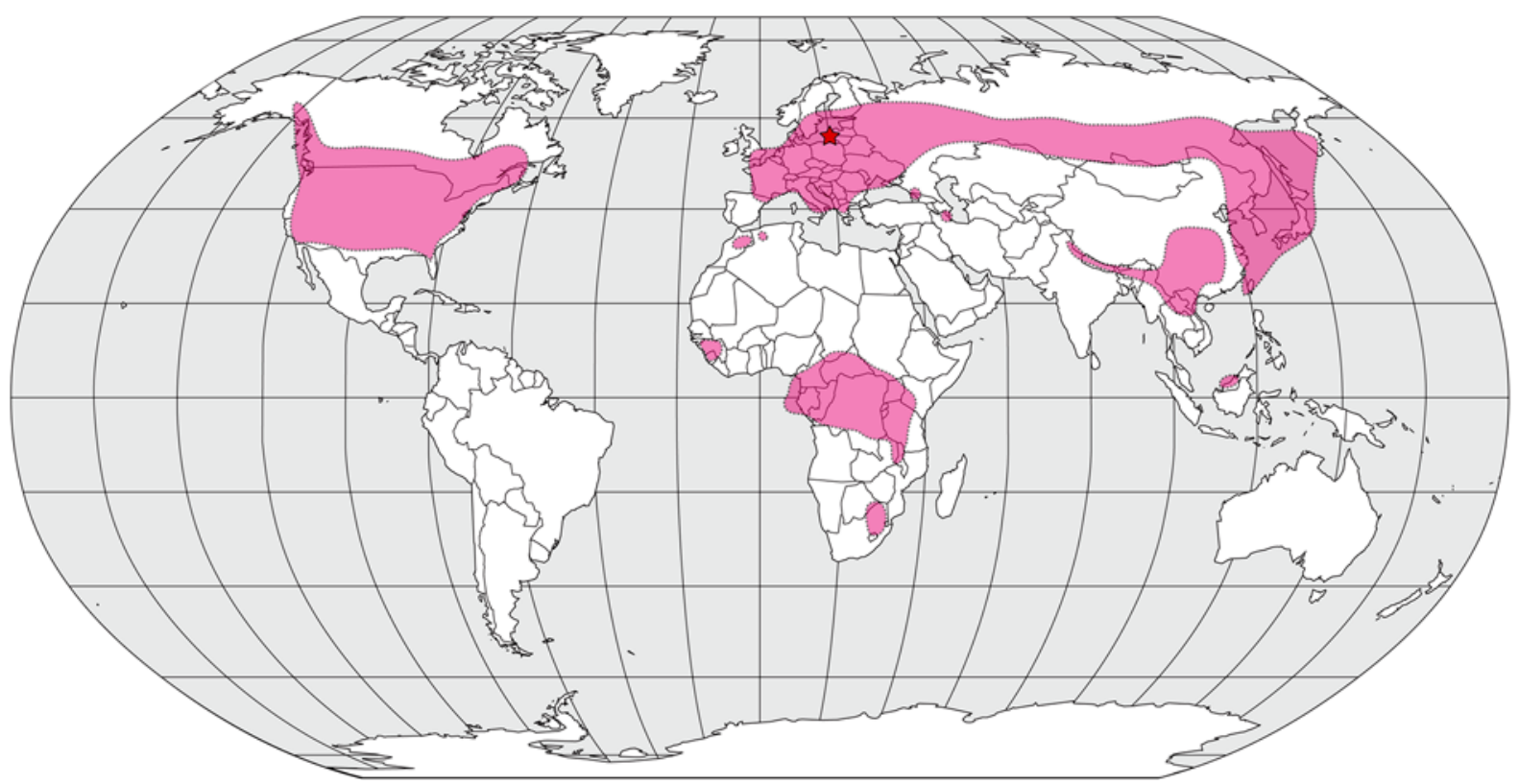

Fig. 15. Current distribution area of the tribe Dictyopterini, with locality ( $\star$ ) for its representatives from Baltic amber (Kolibacium and Helcophorus) [after Kazantsev, 2012b, modified].

Рис. 15. Современное распространие трибы Dictyopterini, с указанием местоположения $(\star)$ находки её представителей из балтийского янтаря (Kolibacium и Helcophorus) [по Kazantsev, 2012b, с изменениями]. 
Lopherotini Kazantsev, 2012

$\uparrow$ Protolopheros Kazantsev, 2013

Protolopheros Kazantsev, 2013: 94. Type species Protolopheros hoffeinsorum Kazantsev, 2013 (original designation)

†hoffeinsorum Kazantsev, 2013: 97. Eocene Baltic amber. Several extant taxa from other genera of Lopherotini in the Eastern Palaearctic and Nearctic (Fig. 16)

Leptolycinae Leng et Mutchler, 1921

Leptolycini Leng et Mutchler, 1921

$\dagger$ Electropteron Kazantsev, gen.n.

Electropteron Kazantsev, gen.n. Type species Electropteron avus Kazantsev, sp.n.

† avus Kazantsev, sp.n. Miocene Dominican amber.

Cessator Kazantsev, 2009

Cessator Kazantsev, 2009: 93. Type species Cessator luquillonis Kazantsev, 2009: 93 (original designation)

$\dagger$ brodzinskyi Ferreira et Ivie, 2017: 58. Miocene Dominican amber. One fossil species from an extant genus, its living species occurring on the island of Puerto-Rico [Kazantsev, 2009].

Dexorinae Kleine, 1933

$\uparrow$ Burmolycini Bocak, Li et Ellenberger, 2019

$\dagger$ Burmolycus Bocak, Li et Ellenberger, 2019

Burmolycus Bocak, Li et Ellenberger, 2019: 152. Type species Burmolycus compactus Bocak, Li et Ellenberger, 2019 (original designation)

$\uparrow$ compactus Bocak, Li et Ellenberger, 2019: 152. Cretaceous Burmese amber.

$\dagger$ Cretolycini Tihelka, Huang et Cai, 2019

$\uparrow$ Cretolycus Tihelka, Huang et Cai, 2019

Cretolycus Tihelka, Huang et Cai, 2019: 263. Type species Cretolycus compactus Tihelka, Huang et Cai, 2019 (original designation)

$\dagger$ praecursor Tihelka, Huang et Cai, 2019: 264. Cretaceous Burmese amber.

\section{Discussion}

In a paper where the tribe Cretolycini, with type genus Cretolycus from Burmese amber, was erected, it was compared only to the extinct Burmolycini and the very divergent extant Dexorini [Tihelka et al., 2019], whereas Cretolycus in fact appears to have more affinities with commonplace extant lycids, such as Dihammatus Waterhouse, 1879 (Platerotini, Lycinae). Still, despite strong doubts about Cretolycus (Cretolycini) eventually ending up in Dexorinae, it seems appropriate to tentatively refrain from transferring the tribe to Lycinae, pending further studies that might cast more light on its morphological characters essential for a more substantiated taxonomic placement.

The fauna of amber net-winged beetles displays certain notable features. In the oldest of them, from ca. 100 myo Cretaceous Burmese amber, two of the three tribes, Burmolycini and Cretolycini, are totally extinct, while the only genus in the extant tribe, Metriorrhynchini (Prototrichalus), does not have any extant members. In ca. 45 myo Eocene Baltic amber all registered tribes of lycids, Lycini, Erotini, Dictyopterini, Lopherotini and Calochromini, are extant, however, all genus-level taxa, although apparently related to extant ones, are extinct (Protolycus, Pseudaplatopterus, Kolibacium and Protolopheros), except one genus (Helcophorus) represented by living species in the East Palaearctic (the actual genus attribution of ' $L y$ gistopterus sp.' signalled by Klebs [1910] needs to be verified). At the same time in ca. 20 myo Miocene Dominican and Mexican amber both lycids tribes, Leptolycini and Platerotini, are extant, as are two of the three genera (Plateros and Cessator).

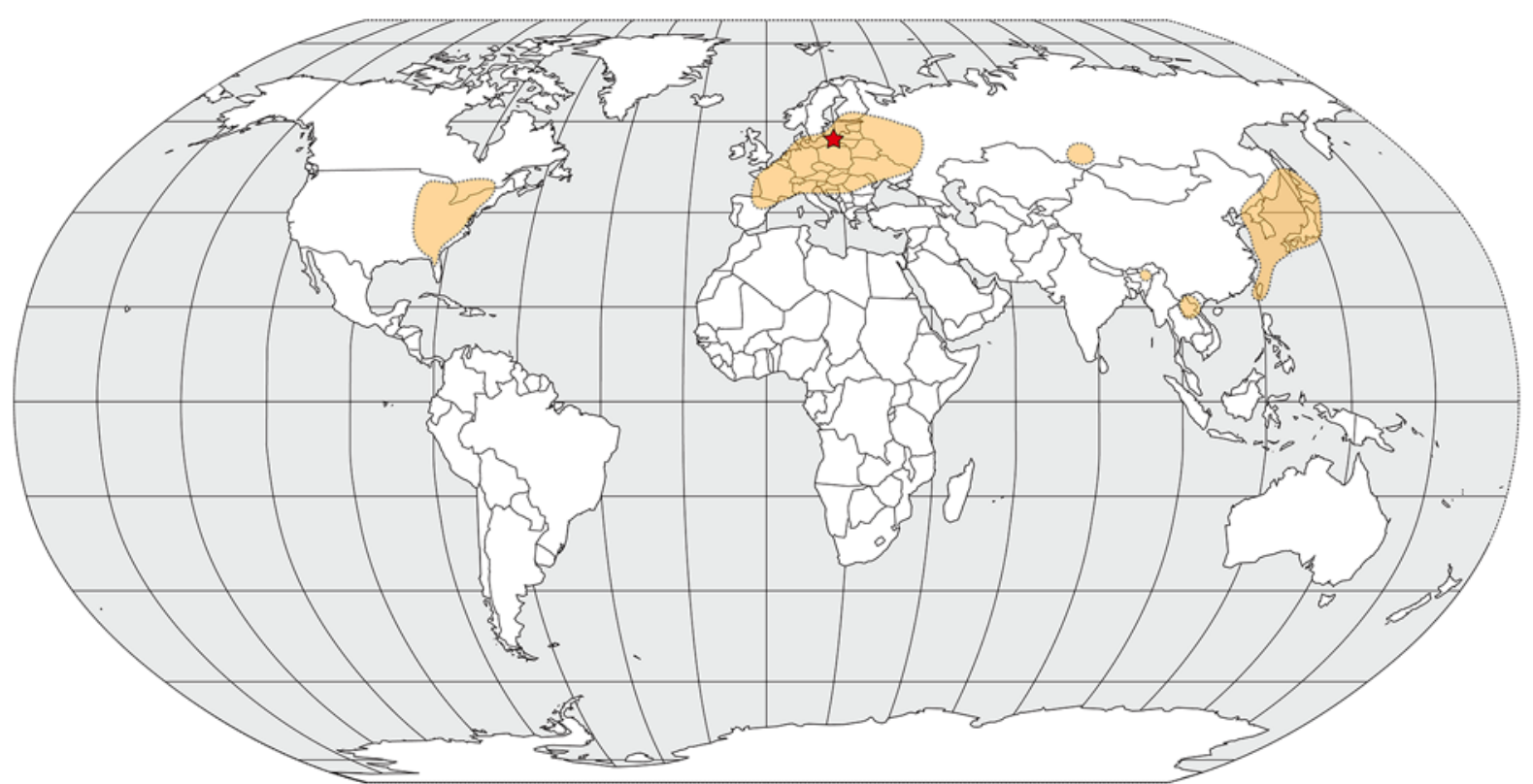

Fig. 16. Current distribution area of the tribe Lopherotini, with locality ( $\star$ ) for its representative from Baltic amber (Protolopheros) [after Kazantsev, 2012b, modified].

Рис. 16. Современное распространие трибы Lopherotini, с указанием местоположения $(\star)$ находки её представителя из балтийского янтаря (Protolopheros) [по Kazantsev, 2012b, с изменениями]. 
The current distribution of the registered in amber lycid tribes also seems to offer some interesting clues. While Burmolycini and Cretolycini are endemic to Cretaceous Burmese amber, Metriorrhynchini, also reported from Burmese amber, is widespread in the Old World, mostly in its tropical areas, but not known in the Americas (Fig. 12). The Eocene Baltic amber lycid tribes demonstrate two different types of current distribution: while that of Lycini lies in nearly all biogeographical realms, with the noticeable near absence in the Holarctic and conspicuous absence in any vicinity of the Baltic amber deposits (Fig. 13), Erotini, Dictyopterini and Lopherotini, on the contrary, show mostly Holarctic or Palaearctic distribution, with Dictyopterini conspicuously penetrating into the Afrotropical and less conspicuously into the Oriental realms (Figs 14-16). As for Miocene Dominican and Mexican amber, one of their Lycidae tribes, Leptolycini, is confined to Central America, Greater Antilles, and mostly northern part of South America (e.g. Kazantsev, 2009, 2017), i.e. around the place where its amber member was found, while the other, Platerotini, is distributed in all biogeographic realms, mostly in the Palaeotropics (e.g. Kleine, 1933; Kazantsev, 2011), with a considerable number of extant members in Mexico [Zaragoza Caballero, 1999].

While presence of Platerotini and Leptolycini in Mexican and Dominican amber, respectively, is uninformative in terms of defining the origin of these tribes due to the young age of the amber, the above-mentioned distribution patterns seem to support the conclusion that at least some of the lycid lineages might have Gondwana (such as Metriorrhynchini) or Laurasia origin (such as Erotini, Dictyopterini and Lopherotini, with Dictyopterini penetrating into modern Afrotropical realm when the isthmus between Laurasia and Gondwana was still broad). If so, the family as a whole should have originated in the times of Pangaea, i.e., at least in the Triassic (245-210 mya). The placement of the group previously referred to as 'Cantharoidea', where net-winged beetles belong, at the root of Elateriformia on the basis of genome sequencing [Kusy et al., 2018], also supported by the morphological evidence (e.g., Kazantsev, 2005), appears to totally conform with such a conclusion, as the origin of Elateridae, a more derived lineage of Elateriformia, has proven to trace back to the Triassic [Kundrata et al., 2020].

Acknowledgements. It is my pleasant duty to express gratitude to Mr. Antonio Ramirez Jardines (Museum of Lúzmica, San Cristobal, Chiapas, Mexico) and Mr. A. Allen (Boise, Idaho) for the possibility to study the Mexican and Dominican amber inclusions. My thanks are also due to $\mathrm{Mr}$. Carsten Gröhn (Hamburg, Germany) for the photos of Plateros jardinesi sp.n. and Prof. Kirill V. Makarov (Moscow) for his help with the colour photos of Electropteron avus gen.n., sp.n.

\section{References}

Bocak L., Li Y., Ellenberger S. 2019. The discovery of Burmolycus compactus gen. et sp. nov. from the mid-Cretaceous of Myanmar provides the evidence for early diversification of net-winged beetles (Coleoptera, Lycidae) // Cretaceous Research. Vol.99. P.149-155. https://doi.org/10.1016/j.cretres.2019.02.018.
Ferreira V., Ivie M. 2017. The first fossil species of the extant genus Cessator Kazantsev (Coleoptera: Lycidae): a new Leptolycini from Dominican Amber // The Coleopterists Bulletin. Vol.71. No.1. P.57-60.

Kazantsev S.V. 2005. Morphology of Lycidae with some considerations on evolution of the Coleoptera // Elytron. Vol.17-18 (2004) et Coleopterological Monographs. Vol.3. P.73-248.

Kazantsev S.V. 2009. Leptolycini of Puerto Rico (Coleoptera, Lycidae) // Russian Entomological Journal. Vol.18. No.2. P.87-95.

Kazantsev S.V. 2011. New and little known taxa of Platerotini, with a note on biogeography of the tribe (Lycidae, Coleoptera) // Russian Entomological Journal. Vol.20. No.2. P.151-187.

Kazantsev S.V. 2012a. New taxa and a checklist of Afrotropical Metriorrhynchini (Lycidae, Coleoptera), with a note on biogeography of the tribe // Russian Entomological Journal.Vol.21. No.1. P.23-33.

Kazantsev S.V. 2012b. A review of Erotinae and Dictyopterinae (Lycidae, Coleoptera), with description of new taxa and a note on biogeography of the subfamilies // Russian Entomological Journal. Vol.21. No.4. P.395-414.

Kazantsev S.V. 2012c. A new lycid genus from the Dominican Amber (Insecta, Coleoptera, Lycidae, Leptolycinae, Leptolycini)// Psyche. Nos.1-3. https://doi:10.1155/2012/982141.

Kazantsev S.V. 2013. A new fossil genus of net-winged beetles, with a brief review of amber Lycidae (Insecta: Coleoptera) // Zootaxa. Vol.3608. No.1. P.94-100.

Kazantsev S.V. 2015. New taxa of Helcophorus Fairmaire, 1891, with a key to species of the genus (Coleoptera: Lycidae) // M. Hartmann, J. Weipert (eds.). Biodiversität und Naturausstattung im Himalaya. Band 5. Erfurt: Verein der Freunde \& Förderer des Naturkundemuseums Erfurt e.V. P.383-389.

Kazantsev S.V. 2017. New leptolycines from Ecuador and Peru (Coleoptera: Lycidae) // Russian Entomological Journal. Vol.26. No.2. P.127-146.

Kazantsev S.V. 2019. Protolycus gedaniensis gen. n., sp. n., the first Baltic amber representative of Lycini (Coleoptera, Lycidae, Lycinae) // Palaeoentomology. Vol.3. No.1. P.327-332. https:/ /doi.org/10.11646/palaeoentomology.2.4.5.

Klebs R. 1910. Über Bernstein einschlösse im allgemeinen und die ColeopterenmeinerBernsteinsammlung//Schriften derPhysikalischökonomischen Gesellschaft zu Königsberg. B.51. H.3. S.217-242.

Kleine R. 1933. Pars 123: Lycidae// Coleopterorum Catalogus auspiciis et auxilio W. Junk editus a Schenkling. Berlin: W. Junk. 145 S.

Kleine R. 1940. Eine Lycidae aus dem baltischen Bernstein // Entomologische Blätter. B.36. H.6. S.179-180.

Kleine R. 1941. Nachtrag zu meiner Arbeit: "Eine Lycidae aus dem baltischen Bernstein" // Entomologische Blätter Bd.37. S.47.

Kundrata R., Packova G., Hoffmanova J. 2020. Fossil Genera in Elateridae (Insecta, Coleoptera): A Triassic Origin and Jurassic Diversification // Insects. Vol.11. No.6(394). P.1-30. https:// doi.org/10.3390/insects 11060394 .

Kusy D., Motyka M., Bocek M., Vogler A.P., Bocak L. 2018. Genome sequences identify three families of Coleoptera as morphologically derived click beetles (Elateridae) // Scientific Reports. Vol.8. P.1-9. https://doi.org/10.1038/s41598-018-35328-0.

Molino-Olmedo F., Ferreira V.S., Branham M.A., Ivie M.A. 2020. The description of Prototrichalus gen. nov. and three new species from Burmese amber supports a mid-Cretaceous origin of the Metriorrhynchini (Coleoptera, Lycidae) // Cretaceous Research. Vol.111. No.104452. P.1-8. https://doi.org/10.1016/ j.cretres.2020.104HYPERLINK "https://doi.org/10.1016/ j.cretres.2020.104452"452.

Riquelme F., Alvarado-Ortega J., Ramos-Arias M., Hernández M., Le Dez I., Lee-Whiting Th.A., Ruvalcaba-Sil J.L. 2014. A fossil stemmiulid millipede (Diplopoda: Stemmiulida) from the Miocene amber of Simojovel, Chiapas, Mexico // Historical Biology. Vol.26. P.415-427. https://doi.org/10.1080/08912963.2013.778843.

Tihelka E., Huang D., Cai C. 2019. A new genus and tribe of Cretaceous net-winged beetles from Burmese amber (Coleoptera: Elateroidea: Lycidae) // Palaeoentomology. Vol.2. No.3. P.262270. https://doi.org/10.11646/palaeoentomology.2.3.11.

Winkler J.R. 1987. Three new genera of fossil Lycidae from Baltic Amber // Mitteilungen der Münchner Entomologischen Gesellschaft. Bd.77. S.61-78.

Zaragoza Caballero S. 1999. Cantharoidea (Coleoptera) de México. III. El genero Plateros Bourgeois (Lycidae: Erotinae: Platerodini) // Acta zoológica mexicana (n.s.). Vol.78. P.1-71. 